\title{
Primary and secondary prevention of breast cancer
}

\author{
Agnieszka Kolak', Marzena Kamińska², Katarzyna Sygit ${ }^{3}$, Agnieszka Budny' ${ }^{1}$ Dariusz Surdyka', \\ Bożena Kukiełka-Budny², Franciszek Burdan ${ }^{4}$ \\ 1 St. John's Cancer Center, Department of Radiotherapy, Lublin, Poland \\ 2 St. John's Cancer Center, Department of Oncology, Lublin, Poland \\ ${ }^{3}$ University of Szczecin, Faculty of Physical Education and Health Promotion, Szczecin, Poland \\ ${ }^{4}$ Human Anatomy Department, Medical Univeristy of Lublin, Poland \\ Kolak A, Kamińska M, Sygit K, Budny A, Surdyka D, Kukiełka-Budny B, Burdan F. Primary and secondary prevention of breast cancer. Ann \\ Agric Environ Med. 2017; 24(4): 549-553. doi: 10.26444/aaem/75943
}

\section{Abstract}

Introduction. Breast cancer is the most common cancer among women and is the second cancer frequently occurring worldwide of newly-diagnosed cancers. There is much evidence showing the influence of life style and environmental factors on the development of mammary gland cancer (high-fat diet, alcohol consumption, lack of physical exercise), the elimination of which (primary prevention) may contribute to a decrease in morbidity and mortality. Secondary prevention, comprising diagnostic tests (e.g. mammography, ultrasonography, magnetic resonance imaging, breast self-examination, as well as modern and more precise imaging methods) help the early detection of tumours or lesions predisposing to tumours. Objective. The aim of this study paper is to review current knowledge and reports regarding primary and secondary prevention of breast cancer.

State of knowledge. It is estimated that nearly $70 \%$ of malign tumours are caused by environmental factors, whereas in breast cancer this percentage reaches $90-95 \%$. There are national programmes established in many countries to fight cancer, where both types of prevention are stressed as serving to decrease morbidity and mortality due to cancers.

Conclusions. Cancer prevention is currently playing a key role in the fight against the disease. Behaviour modification, as well as greater awareness among women regarding breast cancer, may significantly contribute towards reducing the incidence of this cancer. Another important aspect is the number of women undergoing diagnostic tests, which still remains at an unsatisfactory level.

\section{- Key words}

breast cancer, primary and secondary prevention, risk factors, life style, mammography, modern diagnostics methods

\section{INTRODUCTION}

In 2012, regardless of gender, breast cancer was the second most frequently diagnosed cancer worldwide, with a frequency adding up to $11.9 \%$. It is also the first most frequently occurring cancer among women $[1,2,3]$, comprising $25.2 \%$ of all newly-diagnosed cancers [1]. It is assumed that one in eight women in the world will develop mammary gland cancer [4], and that only $5-10 \%$ of all cases of this cancer are caused by genetic disorders, whereas the remaining $90-95 \%$ of cases are connected to environmental factors and life style [5]. Therefore, an essential element of modern medicine is to conduct multidisciplinary research targeted at the enhancing efficiency of health prevention by focusing on primary prevention, risk factors modification to early detection of the disease, quick beginning of treatment (secondary prevention), as well as observation. The main goal is to reduce continuously increasing morbidity, mortality, and economic costs as a result of breast cancer [6].

Various genetic and environmental factors, especially those co-existing, increase the risk of morbidity and reactivation of gland mammary cancer. Environmental and life style factors include: ionizing radiation, hormonal therapy, reproductive behaviours (preferences) of women (e.g. late age of first labour), alcohol [6], as well as other dietary factors, obesity and lack of physical activity $[6,7,8]$. Other commonly recognized and documented risk factors include age and

Address for correspondence: Agnieszka Kolak, St. John's Cancer Center, Department of Radiotherapy, Lublin, Poland

E-mail: agkola@interia.pl

Received: 4 February 2017; accepted: 18 May 2017; first published on June 30, 2017 cancer burden in family, especially breast cancer burden [9]. This cancer occurs most frequently among women in the menopausal transition ( $80 \%$ of disease recognitions among women aged 50 or older) [10].

Primary prevention. Primary prevention consists of eliminating the causes leading to the disease occurrence, and increasing or enhancing the immune system in the population [11].

Diet. In 2007, World Cancer Research Fund / American Institute for Cancer Research (WCRF/AICR) analyzed a lot of research regarding the impact of diet and physical activity on cancer development, confirming that there is a connection between the two. According to recommendations, a healthy diet in cancer prevention is a diet that helps maintain proper body weight, is rich in fruit, vegetables, cereals and legumes, contains little red meat and little salt, and does not consist of processed meat. Moreover, it is characterized by avoiding sweet beverages and reducing the consumption of highcalories food and alcohol beverages $[12,13]$. Food factors (e.g. edible fats) may also cause reversible epigenetic changes (DNA hypomethylation, hypermethylation of promoter region of tumour suppressor genes and abnormal modification of histones) leading to oncogenesis [14].

Essential diet ingredients increasing the risk of mammary gland cancer include trans-fatty acids; their detrimental influence is exercised through disorders in metabolic processes and signal pathways, increase in the level of lipids in blood, inflammation stimulation, dysfunction of vascular endothelium, increase in abdominal obesity, body weight and 
insulin resistance. Increased consumption of high glycaemic index products also significantly influences the risk increase of cancer $[12,13]$.

A very important and favourable diet ingredient is vegetable fibre, which stimulates bacterial anaerobic fermentation in the large intestine, leading to the production of short-chain fatty acids: acetate, propionate and butyrate. In scientific research on cellular lines, butyrate decreases cell proliferation and intensifies apoptosis. Moreover, decrease in the level of circulating estrogen and androstenedione among people consuming a lot of fibre was also reported. Furthermore, products rich in fibre are an essential source of phytoestrogens (working in the human body like estrogens), changing the activity of estrogen receptors and interacting with them, thus contributing to reducing the risk of developing tumour diseases dependent on the endocrine system, especially breast cancer $[12,13]$. In meta-analysis of 16 prospective examinations related to fibre consumption and breast cancer risk, Aune et al. [2012] proved that there is a reverse relation between fibre occurring in diet and the frequency of tumour prevalence [15]. Moreover, another study [Aune et al.] proved a correlation between the concentration of beta-carotene, alpha-carotene and lutein, and the risk decrease of breast cancer morbidity. These observations are crucial from the practical point of view since the source of carotenoids in diet are commonly consumed vegetables and fruit. Epidemiological research shows that the consumption of carrots and broccoli, as well as green and fresh vegetables, correlates with the most with the concentration of alpha- and beta-carotene, as well lutein / zeaxanthin, whereas citrus fruit are related to the concentration of lutein in blood [16].

Obesity. Excessive consumption of high-calorie meals leads to weight gain and eventually to obesity, which is related to higher cancer risk $[13,17,18]$. Obesity is a result of long-term increased energy consumption against energy expenditure [19]. A commonly used index determining underweight, overweight and obesity is the body mass index (BMI), which is calculated by dividing body weight in kilograms by the square of height in meters $\left(\mathrm{kg} / \mathrm{m}^{2}\right)$. BMI range include: $<18.50$ (underweight), 18.5-24.99 (normal body weight), $\geq 25.00$ (overweight), $\geq 30.00$ (obesity) [20, 21]. A lot of scientific research showed that calorie limitation impedes the process of neoplasia. Mechanisms combining obesity with cancer risk include hyperinsulinaemia and insulin resistance, increased production of insulin-like growth factors (IGF), change of sex hormone metabolism, chronic inflammation, change in production by fatty tissue adipocytokines and vascular endothelial growth factors (VEGF), oxidative stress and changes in immune response [13]. Protani et al. carried out between 1963-2005, meta-analysis of 43 examinations among women diagnosed with cancer. The group of women who were already obese when the disease was recognized was characterized by a $33 \%$ higher mortality risk than women with normal body weight $[22,23]$. Hauner et al. came to similar conclusions by assessing examinations and metaanalyses which were published between 1996-2010 [24]. The significance of obesity as a risk factor is increasing with age, especially after menopause $[6,25,26]$, since tumours are characterized by worse response to treatment and great risk of relapse in this period $[6,27]$, whereas women before and after menopause are characterized by worse survival [28]. Similar conclusions were drawn from a meta-analysis of 82 examinations carried out by Chan et al. [2014], since worse overall survival among patients with breast cancer is recognized among women with higher BMI $\left(\geq 30.0 \mathrm{~kg} / \mathrm{m}^{2}\right)$. According to the authors' observations, maintaining normal body weigh reduces the risk of breast cancer development, improves prognosis and reduces the possibility of occurrence of oncological treatment complications [28]. It was also shown that patients with normal body weight are less prone to cancer relapse, diabetes and cardiovascular diseases [6]. Overweight and obesity aggravate the prognosis for the long-term follow-up period among women who received anti-cancer therapy [29].

Alcohol. The risk of cancer increases depending on alcohol dose in combination with biological mechanisms, where ethanol and its genotoxide metabolism and acetaldehyde play an important role [30]. When consuming $10 \mathrm{~g}$ of ethanol daily the risk of breast cancer increases by $8 \%$ in the postmenopausal period, by $9 \%$ before menopause and by $10 \%$ in general [31]. It is suggested that there are 3 mechanisms that explain alcohol influence on the development of mammary gland cancer: impact on the level of estrogens, estrogen receptors and development of alcohol metabolism by-products $[32,33]$. Alcohol has also an impact on estrogen pathway through activating aromatase. Additionally, it can exert influence on the menstrual cycle by decreasing changeability and frequency of cycle length. Big alcohol consumption is connected to the elevated level of estrogen in the luteal phase, whereas a large amount of consumed alcohol during weekends is related to very high level of estrogen in blood. One of the hypotheses suggests alcohol impact on mammary gland cancer development through the cumulative level of endogenous estrogen throughout the whole life. Research conducted by Frydenberg et al. on 202 women showed that daily consumption of beverages containing $>10 \mathrm{~g}$ of alcohol for a week increases the concentration of $17 \beta$-estradiol, on average by $18 \%$ during the menstrual cycle, compared to women reporting the consumption of $<10 \mathrm{~g}$ of alcohol, which confirms a positive relationship between this sex hormone and breast cancer development [34]. Between 1980-2010, Cao et al. conducted 2 prospective observation examinations on 88,084 women and 47,881 men in the United States, examining alcohol impact on cancer development. Breast cancer was the main and most frequently occurring malign tumour related to alcohol consumption. Collected data proved that an alcohol consumption of 5-14.9g daily increases the risk of breast cancer (relative risk 1.13) [35].

Physical activity. Physical activity has a positive impact on mental health among patients suffering from malign tumours [36], and is defined as each body movement made by the skeletal muscles that results in energy consumption [37]. The connection between breast cancer and physical activity is stronger among women who have undergone the menopause [5], have a negative family history regarding this cancer and maintain proper body weight, as well as among women who have given birth to at least one healthy baby [38]. Epidemiological research suggests that the intensity of exercises, starting from moderate to energetic, reduces the risk of breast cancer by roughly $10-25 \%$, compared to inactive women. A precise plan and amount of exercises required to prevent this cancer have not been determined; however, risk decrease is observed along with the increase 
of workout length and intensity [39]. WCRF recommends at least 30 minutes of moderate physical activity undertaken daily and the equivalent to a quick walk in the prevention of any cancer $[12,39]$, and reducing sedentary activity, such as watching TV [12]. Lahart et al. report about reverse a relationship between physical activity and risk of death and development of mammary gland cancer in every case of this disease. Nonetheless, physical activity after cancer has been diagnosed is connected to greater reduction of death risk among women who have undergone the menopause, compared to women who are not yet facing it [40].

Secondary prevention. Secondary prevention aims at terminating the process of disease development before its full symptoms are diagnosed, which may impede or prevent the development of a malign tumour [11]. Screening is the main example of such a prevention, and is targeted at specified groups of the healthy population characterized by a greater risk, for instance [41]: mammography in breast cancer or colonoscopy in colon cancer $[11,41]$. The main result of such prevention should be a decrease in mortality due to cancer thanks to its early detection $[41,42]$.

Mammography. Mammography screening in Poland (MMG) is a screening testing for mammary gland cancer, to which women in the age group 50-69 are subject once in 2 years. This programme has been in operation since 2005 in the whole country [41]. Mammography is not recommended for women at moderate risk of breast cancer, under 40-years-old since ionizing radiation may induce the process of tumour development, and the risk is higher for younger women, especially if they had been exposed before they turned 30-years-old. The disease latency period lasts 10 years, whereas increased risk lasts throughout the whole life. The main disadvantage of MMG is over-recognition, which adds up to around $33 \%$ of all breast cancer detections [43], defined as detection of malign tumour by means of imaging, then confirmed histologically, which would not develop into a full symptom disease during the patient's lifetime [44]. Additionally, over 75\% of lesions detected in mammography are detected as pathologically mild [45]. MMG sensitivity in mammary gland where glandular tissue dominates amounts to $90-95 \%$, whereas in tissue of high density it amounts to $60-75 \%$ [46]. In spite of these observations, mammographic assessment is still considered the best tool for diagnosing breast cancer at its early stage, when the chance of survival treatment possibilities are the best [44]. Moreover, mammography performed currently uses digital quality by receiving an image directly on a computer (digital mammography) [43]. It may also help in thoroughly evaluating the local disease stage and reaction to treatment, as well being used to conduct biopsy under MMG control [47]. This imaging method decreases death risk by 15-20\%, which proves these observations [48].

Ultrasonography (USG). Breast examination by means of ultrasonography is safe - there is no ionizing radiation and non-invasive. It is mostly used to complement other diagnostic examinations, as well as to conduct biopsy under USG control. Its disadvantage is low specificity [43]. USG sensitivity in detecting neoplastic lesions amounts to only $36 \%$ [48]. Ultrasonography allows differentiation between cystic lesions and solid lesions, and is useful in the evaluation of lesions in the pre-operative period and during the followup period, after termination of the treatment process. USG is a valuable examination among women at high risk, as well as at breast evaluation of high density (especially among young women) [43, 49], since MMG is limited [43].

Magnetic Resonance Imaging (MRI). Mammary gland examination by means of magnetic resonance imaging is similarly to USG - non-invasive and safe (no X-radiation). It mostly complements mammography by increasing the detection of malignant lesions $[43,50]$. However, MRI is a more invasive examination compared to MMG since it is conducted using an intravenous contrast agent, although this agent is less sensitizing than that administered during computed tomography (CT) [43]. MR sensitivity amounts to $88.1 \%$ [48]. Its advantage is incredibly precise imaging of soft tissues, which cannot be completed using other methods [43]. The presence of gene mutation among young women is an indication to carry out diagnosis by means of MR [48] (BRCA1, BRCA2) [51]. Breast examination using this method does not always allow differentiation between a malignant lesion and a benign lesion (e.g. fibroadenoma), which may lead to false positive results. MR is still an expensive examination and not available in every medical centre. Moreover, the combination of MMG and breast MR is not currently recommended [43].

Breast Self-Examination (BSE). Breast self-examination applied as a self-method is not a sufficient, but still an important element in helping detect cancer at an early stage. It is a cheap method, generally available and does not demand any complex technical training [52], and can be performed in the home environment [48]. BSE allows woman to learn about proper breast structure which helps later detect untypical lesions in mammary gland tissue [52]. Experts from (Population Programme for Early Breast Cancer Detection (Populacyjny Program Wczesnego Wykrywania Raka Piersi) conducted as part of a national programme to fight cancer in Poland, recommend performing breast self-examination once a month by every woman above the age of 20 , preferably on the first day after the termination of menstruation. Women who have undergone the menopause should also examine their breasts once in a month, preferably on the same day every month [53]. BSE sensitivity is low (12-14\%). Its disadvantage is also a high index of false positive results and over-recognition; thus, BSE should always be complemented by objective imaging examination [48].

Modern and non-standard imaging methods. Highdefinition digital mammography is one of the modern imaging methods of mammary glands and is used in combination with iodinated contrast agents. Images before and after contrast administration are obtained during one examination. Its advantage is in obtaining many after-contrast phases in order to examine the potential capture and washing of the contrast agent by suspicious changes Its disadvantage is the necessity to keep pressure on the breast for a long time during the examination (5-10 minutes), resulting in discomfort for the patient, and the great possibility that the patient may move, which causes a false image recording and necessity to administer an additional intravenous contrast agent.

Contrast-enhanced spectral mammography (CESM) allows a number of images to be received from both breasts 
after a one-off administration of the contrast agent. In this examination, after intravenous marker administration, every image consists of a quickly-received pair of images of low and high energy. Low-energy images are made using the same dose as in digital mammography, while highenergy images have only around $20 \%$ of this dose. CESM enables the demonstration of lesions characterized by bigger vascularization and extracellular leakage of the contrast agent. It is also characterized by high negative predictive value and is similar to the index value of false positive results of MRI [47].

Optical mammography uses the range of wave lengths close to infrared $(650-1,000 \mathrm{~nm})$, providing structural and functional information. Image contrast is made by haemoglobin absorption and other dominant tissues, such as water and lipids. Functional information is received by means of spectroscopic methods that detect oxygen saturation in tissues, which help assess the metabolism of breast tissue. The main advantages of this examination is lack of ionizing radiation, non-invasiveness, low performance cost, relatively cheap equipment [43], shorter imaging time compared to magnetic resonance imaging, and perfect timeresolution [48]. The elementary limitation of optical breast imaging is relatively low spatial resolution in comparison to traditional techniques, such as mammography using ionizing radiation. Nowadays, this method is used by means of digital technologies [43].

Radiothermometry mammography (RTM) is based on a thermal imaging system that measures and analyses the breast surface and internal temperature. RTM is a sensitive method supporting breast cancer diagnosis. RTM equipment measures electro-magnetic waves sent by the breast tissue in order to identify a specific area. It is possible to diagnose cancer by means of this method using thermal activity of cancerous cells before structural lesions in breast tissue occur. RTM allows to differentiate dysplasia from neoplastic lesions. It is a safe examination since it is performed without ionizing radiation and may encompass the imaging area to include the axillary cavity [45].

Scintimammography (SMM) is an imaging technique, in which non-specific radio-markers are used to identify malignant lesions. SMM usually helps verify lesions noticed in mammography. This examination is also useful after primary therapy and adjuvant treatment in order to evaluate response to treatment and early detection of disease relapse, as well as necrosis in the examined area. SMM is more specific than MRI and, as a result, is used to detect lesions bigger that onr centimeter diameter.

Positron emission tomography (PET) is an examination where the most frequently used radio-marker is 18F-fluorodeoxyglucose. In PET examination, glucose metabolism is used in order to detect malignant and metastatic lesions, especially from solid tumours. Advanced usage of breast imaging by means of nuclear energy include positron emission mammography (PEM) and PET/CT. PEM is used to illustrate only mammary gland tissues, in contrast to PET examination which encompass the whole body and is the best screening tool among women characterized by high risk. PET / CT is an imaging method combining PET (providing functional information) and computed tomography that provides anatomic information [48].

\section{CONCLUSIONS}

Primary and secondary prevention has a significant impact on morbidity and the detection of cancer. Modern life-style and various easily accessible stimulants contribute to the fact that life-style and environmental factors are playing a greater role in breast cancer development. Living in big urban agglomerations causes the situation where women do not have time to properly take care of their health, or await diagnostic examinations for a long time. On the other hand, there is worse accessibility to imaging examinations in smaller cities. Extending women's knowledge regarding the impact of their behaviour on breast cancer development and educating them about the possibilities to gain control over this disease by implementing modifications of their habits is an important aspect. Although the awareness of Polish society on the subject of cancer is increasing, the number of women reporting for diagnostic examinations is still too low, which leads to constantly increasing mortality caused by cancer. Nonetheless, every method of mammary gland imaging demands further research conducted on bigger groups of patients before they are applied in daily diagnostic practice.

\section{REFERENCES}

1. Worldwide cancer statistics (WCRF) [Internet]. 2015 [cited 2015 November 5]. Available from: http://www.wcrf.org/cancer_statistics/ world_cancer_statistics.php.

2. Mermer G, Turk M. Assessment of the Effects of Breast Cancer Training on Women Between the Ages of 50 and 70 in Kemalpasa, Turkey. Asian Pac J Cancer Prev. 2014; 15(24): 10749-10755. [Crossref]

3. Leśniczak B, Krasomski G, Oszukowski P, Stetkiewicz T, Woźniak $\mathrm{P}$. Incidence of and mortality from breast cancer among women in Poland in the years 2001-2010. Prz Menopauzalny. 2014; 13(6): 344-347. [Crossref]

4. Ferrini K, Ghelfi F, Mannucci R, Titta L. Lifestyle, nutrition and breast cancer: facts and presumptions for consideration. Ecancermedicalscience. 2015; 9: 1-11. [Crossref]

5. Castelló A, Martín M, Ruiz A, Casas AM, Baena- Cañada JM, Lope V et al. Lower Breast Cancer Risk among Women following the World Cancer Research Fund and American Institute for Cancer Research Lifestyle Recommendations: EpiGEICAM Case-Control Study. PLoS One. 2015; 10(5): 1-15. [Crossref]

6. Coughlin SS, Smith SA. The Impact of the Natural, Social, Built, and Policy Environments on Breast Cancer. J Environ Health Sci. 2015; 1(3): 1-7. [Crossref]

7. Podkowa N, Komasińska P, Roszak M, Gryczka R, Grodecka-Gazdecka S, Łacka K. Health behaviours among women diagnosed with breast tumours. Pol Merkur Lekarski. 2014; 37(219):153-158.

8. Howell A, Anderson AS, Clarke RB, Duffy SW, Evans DG, GarciaClosas $\mathrm{M}$ et al. Risk determination and prevention of breast cancer. Breast Cancer Research. 2014; 16(5): 1-19. [Crossref]

9. KrukJ. Intensity of recreational physical activity in different life periods in relation to breast cancer among women in the region of Western Pomerania. Contemp Oncol (Pozn). 2012; 16(6): 576-581. [Crossref]

10. Kamińska M, Ciszewski T, Łopacka-Szatan K, Miotła P, Starosławska E. Breast cancer risk factors. Prz Menopauzalny. 2015; 14(3): 196-202. [Crossref]

11. Katz D, Ather A. Preventive Medicine, Integrative Medicine \& The Health of The Public. Commissioned for the IOM Summit on Integrative Medicine and the Health of the Public. 2009. [cited 2015 November 8]. Available from: http://www.iom.edu/ /media/Files/Activity\%20Files/ Quality/IntegrativeMed/Preventive\%20Medicine\%20Integrative\%20 Medicine\%20and\%20the\%20Health\%20of\%20the\%20Public.pdf.

12. World Cancer Research Fund/American Institute for Cancer Research. Food, nutrition, physical activity and the prevention of cancer: a global perspective. Washington, DC: World Cancer Research Fund/ American Institute for Cancer Research. 2007.[Internet]. 2015 [cited 
2015 November 9]. Available from: http://www.aicr.org/assets/docs/ pdf/reports/Second_Expert_Report.pdf.

13. Norata T, Scocciantib C, Boutron-Ruaultc M-C, Andersond A, Berrino F, Cecchini $\mathrm{M}$ et al. European Code against Cancer 4th Edition: Diet and cancer. Cancer Epidemiology. 2015. [cited 2015 November 8]. Available from: http://www.cancerepidemiology.net/article/S18777821(15)00070-3/pdf. [Crossref]

14. Rodríguez-Miguel C, Moral R, Escrich R, Vela E, Solanas M, Escrich E. The Role of Dietary Extra Virgin Olive Oil and Corn Oil on the Alteration of Epigenetic Patterns in the Rat DMBA-Induced Breast Cancer Model. PLoS One. 2015; 10(9): 1-16. [Crossref]

15. Aune D, Chan DSM, Greenwood DC, Vieira AR, Navarro Rosenblatt DA, Vieira $R$ et al. Dietary fiber and breast cancer risk: a systematic review and meta-analysis of prospective studies. Ann Oncol. 2012; 23(6): 1394-1402. [Crossref]

16. Aune D, Chan DSM, Vieira AR, Navarro Rosenblatt DA, Vieira R, Greenwood DC et al. Dietary compared with blood concentrations of carotenoids and breast cancer risk: a systematic review and metaanalysis of prospective studies. Am J Clin Nutr. 2012; 96(2): 356-373. [Crossref]

17. Orecchioni S, Reggiani F, Talarico G, Bertolini F. Mechanisms of obesity in the development of breast cancer. Discov Med. 2015; 20(109): 121-128.

18. Allott EH, Hursting SD. Obesity and cancer: mechanistic insights from transdisciplinary studies. Endocr Relat Cancer. 2015; 22(6): 365-386. [Crossref]

19. Davoodi SH, Malek-Shahabi T, Malekshahi-Moghadam A, Shahbazi R, Esmaeili S. Obesity as an Important Risk Factor for Certain Types of Cancer. Iran J Cancer Prev. 2013; 6(4): 186-194.

20. The WHO Global Database on Body Mass Index (BMI). [Internet]. 2015 [cited 2015 November 10]. Available from: http://apps.who.int/ bmi/index.jsp?introPage=intro 3.html.

21. Jeon YW, Kang SH, Park MH, Lim W, Cho SH, Suh YJ. Relationship between body mass index and the expression of hormone receptors or human epidermal growth factor receptor 2 with respect to breast cancer survival. BMC Cancer. 2015; 15: 1-9. [Crossref]

22. Protani M, Coory M, Martin JH. Effect of obesity on survival of women with breast cancer: systematic review and meta-analysis. Breast Cancer Res Treat. 2010; 123(3): 627-635. [Crossref]

23. Thompson HJ, Sedlacek SM, Wolfe P, Paul D, Lakoski SG, Playdon $\mathrm{MC}$ et al. Impact of Weight Loss on Plasma Leptin and Adiponectin in Overweight-to-Obese Post Menopausal Breast Cancer Survivors. Nutrients. 2015; 7(7): 5156-5176 [Crossref]

24. Hauner D, Janni W, Rack B, Hauner H. The Effect of Overweight and Nutrition on Prognosis in Breast Cancer. Dtsch Arztebl Int. 2011; 108(47): 795-801.

25. World Cancer Research Fund International/American Institute for Cancer Research Continuous Update Project Report: Diet, Nutrition, Physical Activity, and Breast Cancer Survivors. 2014. [Internet]. 2015 [cited 2015 November 8]. Available from: http://www.wcrf.org/sites/ default/files/Breast-Cancer-Survivors-2014-Report.pdf.

26. Rose DP, Gracheck PJ,Vona-Davis L. The Interactions of Obesity, Inflammation and Insulin Resistance in Breast Cancer. Cancers. 2015; 7(4): 2147-2168. [Crossref]

27. Applebaum MA, Miller BT, Lopez J, Doren EL, Laronga C, Smith PD. Change in Body Mass Index After Breast Reconstruction and Associated Complications. Eplasty. 2015; 15: 406-412.

28. Chan DSM, Vieira AR, Aune D, Bandera EV, Greenwood DC, McTiernan A et al. Body mass index and survival in women with breast cancer-systematic literature review and meta-analysis of 82 follow-up studies. Ann Oncol. 2014; 25(10): 1901-1914. [Crossref]

29. Thompson HJ, Sedlacek SM, Playdon MC, Wolfe P, McGinley JN, Paul $D$ et al. Weight Loss Interventions for Breast Cancer Survivors: Impact of Dietary Pattern. PLoS One. 2015; 10(5): 1-17. [Crossref]

30. Schüz J, Espina C, Villain P, Herrero H, Leon ME, Minozzi S et al. European Code against Cancer 4th Edition: 12 ways to reduce your cancer risk. Cancer Epidemiology. 2015. [cited 2015 November 11]. Available from: http://www.cancerepidemiology.net/article/S18777821(15)00127-7/pdf.

31. Scoccianti C, Cecchini M, Anderson AS, Berrino F, Boutron-Ruault $\mathrm{MC}$, Espina $\mathrm{C}$ et al. European Code against Cancer 4th Edition: Alcohol drinking and cancer. Cancer Epidemiology. 2015. [cited 2015 November 11]. Available from: http://www.cancerepidemiology.net/article/S18777821(15)00023-5/pdf.
32. Liu Y, Nguyen N, Colditz GA. Links between alcohol consumption and breast cancer: a look at the evidence.Womens Health. 2015; 11(1): 65-77. [Crossref]

33. Castro GD, Castro JA. Alcohol drinking and mammary cancer: pathogenesis and potential dietary preventive alternatives. World J Clin Oncol. 2014; 5(4): 713-729. [Crossref]

34. Frydenberg H, Flote VG, Larsson IM, Barrett ES, Furberg AS, Ursin G et al. Alcohol consumption, endogenous estrogen and mammographic density among premenopausal women. Breast Cancer Research. 2015; 17: 1-12. [Crossref]

35. Cao Y, Willett WC, Rimm EB, Stampfer MJ, Giovannucci EL. Light to moderate intake of alcohol, drinking patterns, and risk of cancer: results from two prospective US cohort studies. BMJ. 2015; 351: 1-8. [Crossref]

36. Milecki P, Hojan K, Ozga-Majchrzak O, Molińska-Glura M. Exercise tolerance in breast cancer patients during radiotherapy after aerobic training. Contemp Oncol (Pozn). 2013; 17(2): 205-209.

37. Kruk J. Lifestyle Components and Primary Breast Cancer Prevention. Asian Pac J Cancer Prev.2015; 15 (24): 10543-10555. [Crossref]

38. Lynch BM, Neilson HK, Friedenreich CM. Physical activity and breast cancer prevention. Recent Results Cancer Res. 2011; 186: 13-42. [Crossref]

39. Neilson HK, Conroy SM, Friedenreich CM. The Influence of Energetic Factors on Biomarkers of Postmenopausal Breast Cancer Risk. Curr Nutr Rep. 2014; 3(1): 22-34. [Crossref]

40. Lahart IM, Metsios GS, Nevill AM, Carmichael AR. Physical activity, risk of death and recurrence in breast cancer survivors: A systematic review and meta-analysis of epidemiological studies. Acta Oncol. 2015; 54(5): 635-654. [Crossref]

41. Strategia walki $\mathrm{z}$ rakiem w Polsce 2015-2025. [Internet]. 14 czerwca 2014. [cited 2015 November 16]. Available from: http://walkazrakiem. pl/sites/default/files/library/files/strategia_walki_z_rakiem_w_ polsce_2015_2024.pdf.

42. Weigel S, Heindel W, Heidrich J, Heidinger O, Hense HW. Reduction of Advanced Breast Cancer Stages at Subsequent Participation in Mammography Screening. Fortschr Röntgenstr. 2015. [cited 2015 November 16]. Available from: https://www.thieme-connect.com/ products/ejournals/pdf/10.1055/s-0041-107835.pdf. [Crossref]

43. Mehnati P, Tirtash MJ. Comparative Efficacy of Four Imaging Instruments for Breast Cancer Screening. Asian Pac J Cancer Prev. 2015; 16(15): 6177-6186. [Crossref]

44. Morris E, Feig SA, Drexler M, Lehman C. Implications of Overdiagnosis: Impact on Screening Mammography Practices. Popul Health Manag. 2015; 18 (1): 3-11. [Crossref]

45. Caferova S, Uysal F, Balcı P, Saydam S, Canda T. Efficacy and safety of breast radiothermometry in the differential diagnosis of breast lesions. Contemp Oncol (Pozn). 2014; 18(3): 197-203. [Crossref]

46. Çakır M, Küçükkartallar T, Tekin A, Selimoğlu N, Poyraz N, Belviranlı MM et al. Comparison of mammography sensitivity after reduction mammoplasty targeting the glandular and fat tissue. Ulus Cerrahi Derg. 2015; 31(2): 68-71. [Crossref]

47. Łuczyńska E, Heinze-Paluchowska S, Hendrick E, Dyczek S, Ryś J, Herman K et al. Comparison between Breast MRI and ContrastEnhanced Spectral Mammography. Med Sci Monit. 2015; 21: 1358-1367. [Crossref]

48. Godavarty A, Rodriguez S, Jung YJ, Gonzalez S. Optical imaging for breast cancer prescreening. Breast Cancer: Targets and Therapy (Dove Med Press). 2015; 7: 193-209. [Crossref]

49. Hwang JY, Han BK, Ko EY, Shin JH, Hahn SY, Nam MY. Screening Ultrasound in Women with Negative Mammography: Outcome Analysis. Yonsei Med J. 2015; 56(5): 1352-1358. [Crossref]

50. Yang SN, Li FJ, Liao YH, Chen YS, Shen WC, Huang TC. Identification of Breast Cancer Using Integrated Information from MRI and Mammography. PLoS One. 2015; 10(6): 1-11. [Crossref]

51. Weinstock C, Campassi C, Goloubeva O, Wooten K, Kesmodel S, Bellevance $\mathrm{E}$ et al. Breast magnetic resonance imaging (MRI) surveillance in breast cancer survivors. SpringerPlus. 2015; 4: 1-8. [Crossref]

52. Akhtari-Zavare M, Latiff LA, Juni MH, Said SM, Ismail IZ. Knowledge of Female Undergraduate Students on Breast Cancer and Breast Selfexamination in Klang Valley, Malaysia. Asian Pac J Cancer Prev. 2015; 16(15): 6231-6235. [Crossref]

53. Populacyjny program profilaktyki i wczesnego wykrywania raka szyjki macicy i populacyjny program wczesnego wykrywania raka piersi. Ministerstwo Zdrowia 2013. [cited 2015 November 16]. Available from: http://profilaktykaraka.coi.waw.pl/dla-kobiet/profilaktyka-raka-piersi. 